\title{
Propofol induces proliferation partially via downregulation of p53 protein and promotes migration via activation of the Nrf2 pathway in human breast cancer cell line MDA-MB-231
}

\author{
CHAO MENG, LINLIN SONG, JUAN WANG, DI LI, YANHONG LIU and XIAOGUANG CUI
}

\begin{abstract}
Department of Anesthesiology, The Second Affiliated Hospital of Harbin Medical University, and Hei Long Jiang Province Key Laboratory of Research on Anesthesiology and Critical Care Medicine, Harbin, Heilongjiang 150001, P.R. China
\end{abstract}

Received June 6, 2016; Accepted July 14, 2016

DOI: $10.3892 /$ or.2016.5332

\begin{abstract}
Antioxidants induce the proliferation of cancers by decreasing the expression of p53. Propofol, one of the most extensively used intravenous anesthetics, provides its antioxidative activity via activation of the nuclear factor E2-related factor-2 (Nrf2) pathway, but the mechanisms involved in the effects remain unknown. Thus, we aimed to investigate the function of p53 and Nrf2 in the human breast cancer cell line MDA-MB-231 following treatment with propofol. The cells were treated with propofol $(2,5$ and $10 \mu \mathrm{g} / \mathrm{ml})$ for 1,4 and $12 \mathrm{~h}$, and MTT assay was used to evaluate cell proliferation, and a wound healing assay was used to evaluate cell migration. Cell apoptosis, caspase-3 activity, and western blot analysis for p53 and Nrf2 protein were also assessed. Finally, PIK-75, a potent Nrf2 inhibitor, was used to confirm the effects of Nrf2 after treatment with propofol. Treatment of MDA-MB-231 cells with propofol resulted in increased proliferation and migration in a dose- and time-dependent manner. After treatment with propofol for $12 \mathrm{~h}$, the Nrf2 protein expression was increased, while the percentage of apoptotic cells, caspase- 3 activity, and expression of p53 were significantly decreased. Additionally, treatment with the Nrf2 inhibitor increased the percentage of apoptotic cells, inhibited the migration almost completely, and decreased the degree of proliferation, while the expression of p53 was not affected. In conclusion, propofol increased the proliferation of human breast cancer MDA-MB-231 cells, which was at least partially associated with the inhibition of the expression of p53, and induced cell migration, which was involved in the activation of the Nrf2 pathway.
\end{abstract}

Correspondence to: Dr Xiaoguang Cui, Department of Anesthesiology, The Second Affiliated Hospital of Harbin Medical University, 246 Xuefu Road, Harbin, Heilongjiang 150001, P.R. China

E-mail: cuixiaoguang1018@126.com

Key words: propofol, proliferation, migration, MDA-MB-231 cells, p53, Nrf2

\section{Introduction}

Reactive oxygen species (ROS), such as the superoxide and hydrogen peroxide, damage DNA and enzymes, eventually leading to cell and tissue injury and dysfunction (1). Antioxidants, scavenging these free radicals and favored as prophylactic treatment, are used to prevent cardiovascular diseases and cancers to prolong longevity $(2,3)$. However, many studies have shown that antioxidants may induce the proliferation of cancer cells. Serafini et al (4) found that antioxidants displayed an increased risk of distal gastric cancer in a clinical trial of 1.3 million people. A previous study reported that application of antioxidant inhibitors is a useful strategy for the treatment of solid tumors (5). Sayin et al (6) found that antioxidants markedly increased tumor progression and reduced the survival rate via decreasing p53 protein expression in mouse lung cancer. p53 was recognized as a key tumor-suppressor gene, and induced tumor cell apoptosis via the Bcl-2 family $(7,8)$.

Propofol (2,6-diisopropylphenol), one of the most common anesthetic agents widely used in the clinic, contains a hydroxyl to develop its antioxidative property via activating the nuclear factor E2-related factor-2 (Nrf2) pathway $(9,10)$. As a type of antioxidant, the effects of propofol on cancer cells has not been demonstrated $(10,11)$. Additionally, it is still unclear whether the effects of propofol on cancer cells are related to the p53 protein. Therefore, the aim of this study was to investigate the effects of p53 and Nrf2 on human breast cancer cell line MDA-MB-231 after treatment with propofol.

\section{Materials and methods}

Cell culture. Human breast cancer cell line MDA-MB-231 that carries a wild-type p53 gene was obtained from the American Type Culture Collection (ATCC, Manassas, VA, USA), and cultured in complete medium containing RPMI-1640 medium (HyClone, Logan, UT, USA), 10\% fetal bovine serum (FBS) (Gibco Life Technologies, Paisley, UK), and $1 \%$ penicillin/streptomycin mixture (Beyotime Institute of Biotechnology, Shanghai, China). The MDA-MB-231 cells were cultured in a humidified incubator containing $5 \%$ carbon dioxide $\left(\mathrm{CO}_{2}\right) / 95 \%$ air at $37^{\circ} \mathrm{C}$. 
Groups and drug application. The MDA-MB-231 cells were stimulated with propofol $(\geq 97.0 \%$; Sigma-Aldrich Chemical Co., St. Louis, MO, USA) dissolved in dimethyl sulfoxide (DMSO) (Beyotime Institute of Biotechnology) and in complete medium at 2, 5 and $10 \mu \mathrm{g} / \mathrm{ml}$ for 1,4 and $12 \mathrm{~h}$. The DMSO and complete medium without propofol were also tested at an equal concentration and volume as the vehicle-control group (VC group) and normal control group (NC group), respectively. The final concentration of DMSO was less than $0.1 \%$.

Cell proliferation assay. The MDA-MB-231 cells at a density of $2 \times 10^{4}$ cells $/ \mathrm{ml}$ were seeded in 96-well plates at $100 \mu \mathrm{l} / \mathrm{well}$, and incubated for $12 \mathrm{~h}$. After treatment with propofol for the indicated time, the cells were cultivated for an additional $24 \mathrm{~h}$ in the same incubator. Then, $10 \mu \mathrm{l}$ MTT (Wuhan Boster Biological Engineering Co., Ltd., Wuhan, China) was added to each well for another $4 \mathrm{~h}$ of incubation. A $100 \mu \mathrm{l}$ formazan solution was added to each well and shaken for $15 \mathrm{~min}$ in the dark. The absorbance (A) was measured at $562 \mathrm{~nm}$ with a microplate reader (ELX800; BioTek Instruments, Inc., Winooski, VT, USA). The proliferation rate was determined according to the following formula: (A562 of test well - A562 of $\mathrm{NC}$ group well)/(A562 of NC group well - A562 of zero set well) $\mathrm{x} 100 \%$.

Wound healing assay. The MDA-MB-231 cells were seeded in a $30-\mathrm{mm}$ culture dish at a density of $1 \times 10^{6}$ cells. When the cells reached $100 \%$ confluence, the complete medium was replaced by fresh serum-free medium, and incubated for $4 \mathrm{~h}$. Then the cells were wounded across the center of the well into a clean straight edge with a $200-\mu 1$ micropipette tip, and treated with propofol according to the study design. The cell migration ability was assessed by microscopic examination in three fields that were randomly selected along each edge, and the remaining scratch area was evaluated by ImageJ (National Institutes of Health, Bethesda, MD, USA), and the result of wound closure was expressed as the percentage of the initial scratch area.

Apoptosis detection. After treatment of propofol, terminal deoxynucleotidyl transferase dUTP nick-end labeling (TUNEL) staining was used to evaluate cell apoptosis using the Colorimetric TUNEL apoptosis assay kit (Beyotime Institute of Biotechnology) according to the manufacturer's instructions. Apoptosis index, the number of TUNEL-positive cells in every 100 cells, was calculated in three randomly selected fields per section. Additionally, the activity of caspase-3 was detected by the caspase-3 activity assay kit (Beyotime Institute of Biotechnology) following the manufacturer's instructions. The protein concentration was detected by a bicinchoninic acid (BCA) assay (Beyotime Institute of Biotechnology). One unit of caspase-3 enzyme activity is the amount of enzyme that will cleave $1.0 \mathrm{nmol}$ of the colorimetric substrate Ac-DEVD-pNA per hour at $37^{\circ} \mathrm{C}$ under saturated substrate concentrations. The result was expressed as units per milligram of protein $(\mathrm{U} / \mathrm{mg}$ protein).

Western blot analysis. The MDA-MB-231 cells were seeded in 6-well plates at a density of $2 \times 10^{6}$ cells and treated with

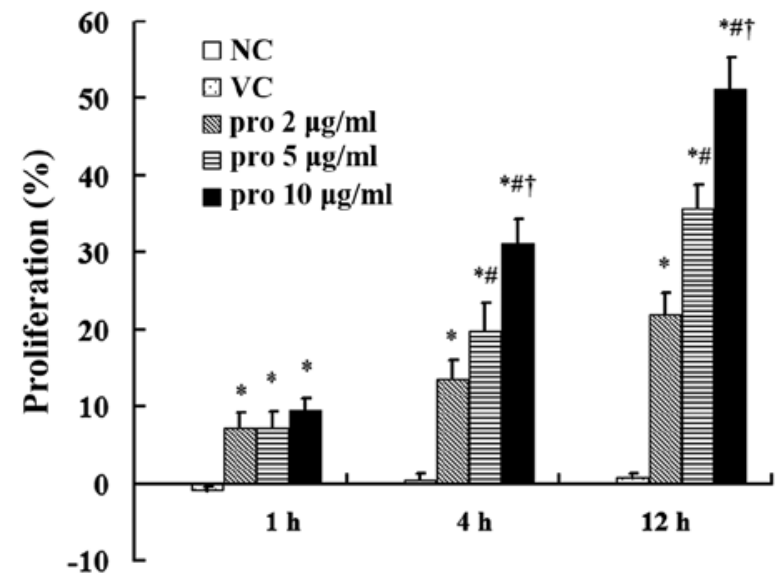

Figure 1. Effect of propofol on cell proliferation. Human breast cancer cell line MDA-MB-231 was treated with propofol at the concentrations of 2, 5 and $10 \mu \mathrm{g} / \mathrm{ml}$ for 1,4 and $12 \mathrm{~h}$. Cell proliferation was determined according to the following formula: (A562 of test well - A562 of NC group well)/(A562 of NC group well - A562 of zero set well) x 100\%. Dimethyl sulfoxide (DMSO, $<0.1 \%$ ) and complete medium without propofol were used as the VC and NC groups. The proliferation of MDA-MB-231 cells after treatment with propofol (pro) was higher than that of the NC group, and the proliferation in the pro $10 \mu \mathrm{g} / \mathrm{ml}$ group was higher than that in the pro 2 and $5 \mu \mathrm{g} / \mathrm{ml}$ groups at $12 \mathrm{~h}(\mathrm{P}<0.05)$. Data are expressed as mean values \pm standard deviations $(\mathrm{n}=3)$. VC, vehicle-control group; NC, normal control group; pro, propofol. ${ }^{*} \mathrm{P}<0.05$ vs. NC group; ${ }^{\#} \mathrm{P}<0.05$ vs. pro $2 \mu \mathrm{g} / \mathrm{ml}$ group; ${ }^{\dagger} \mathrm{P}<0.05$ vs. pro $5 \mu \mathrm{g} / \mathrm{ml}$ group.

propofol. The cells were homogenized with lysis buffer (Beyotime Institute of Biotechnology) for $30 \mathrm{~min}$ to extract the total protein, and the protein concentration was detected by a BCA assay. The lysates were centrifuged at $12,000 \mathrm{x} \mathrm{g}$ for $30 \mathrm{~min}$ and the supernatant was separated by $10 \%$ sodium dodecyl sulfate-polyacrylamide gel electrophoresis and, then electroblotted onto polyvinyl difluoride membranes. After $2 \mathrm{~h}$ of blocking, the primary antibody of p53 $(1: 2,000)$ and $\mathrm{Nrf} 2$ $(1: 2,000)$ (both from ABclonal Biotech Co., Ltd., Cambridge, MA, USA) was used overnight. Then the membrane was incubated with horseradish peroxidase-conjugated antibody (1:5,000; ABclonal Biotech Co., Ltd.) for $1 \mathrm{~h}$. The membranes were developed with diaminobenzidine staining and exposed to film. All gels were repeated three times and the data are expressed as a ratio of targeted protein to $\beta$-actin protein by the integrated density values.

Nrf2 inhibitor treatment. To investigate the effect of Nrf2, the Nrf2 inhibitor (12) at $0.1,0.3$ and $1.0 \mu \mathrm{M}$ (PIK-75; Selleck Chemicals, Houston, TX, USA) was added to the MDA-MB-231 cells for $4 \mathrm{~h}$ before the treatment of propofol $(10 \mu \mathrm{g} / \mathrm{ml})$. The proliferation and wound healing assays were evaluated after the treatment of propofol for $12 \mathrm{~h}$, and the apoptosis index, caspase- 3 activity, and the expression of $\mathrm{p} 53$ and $\mathrm{Nrf} 2$ were detected by western blot analysis.

Statistical analysis. All of the experiments in this study were performed for three repetitions independently, and the data are expressed as mean values \pm standard deviations. Differences between groups were assessed by one-way analysis of variance (ANOVA), and differences between each two groups were analyzed by the Student-Newman-Keuls test. A P-value $<0.05$ was considered statistically significant. 
$\mathbf{A}$

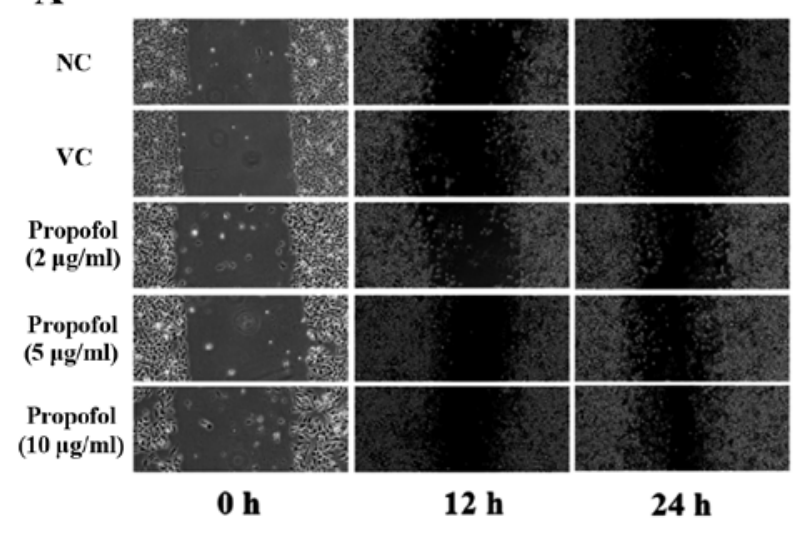

B

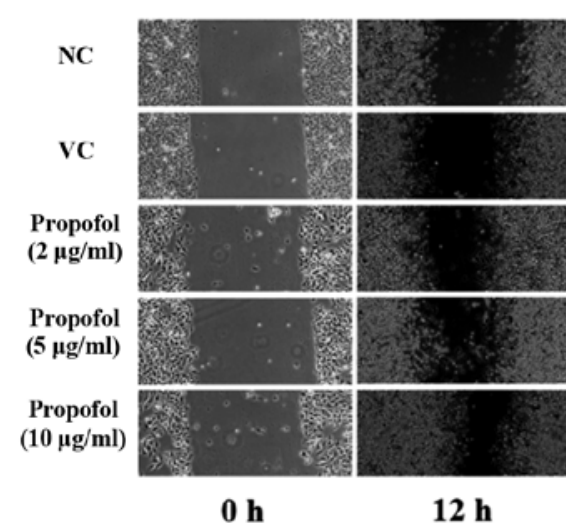

C

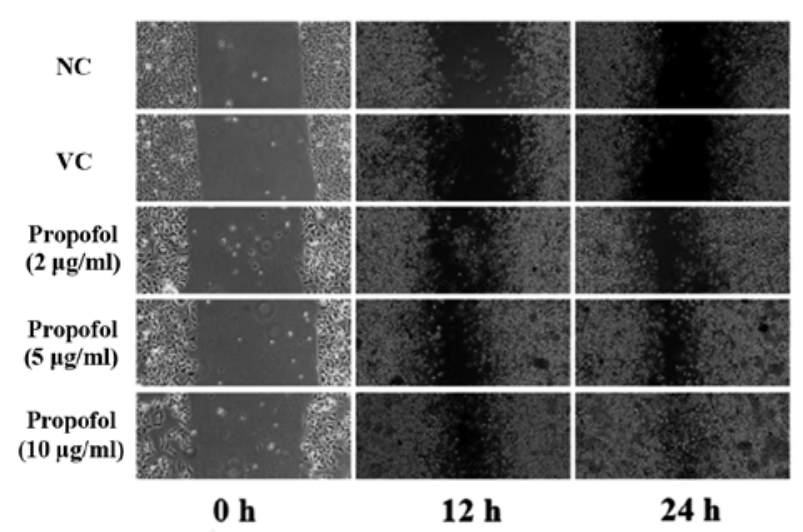

D

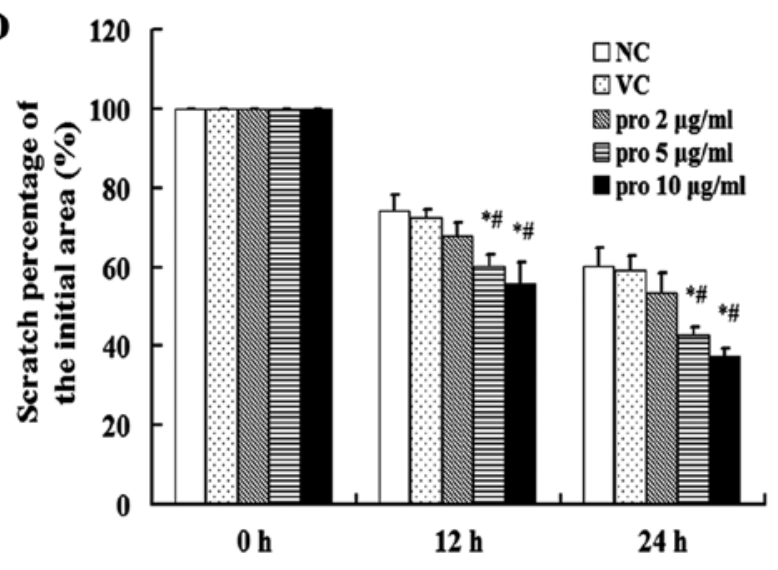

$\mathbf{E}$

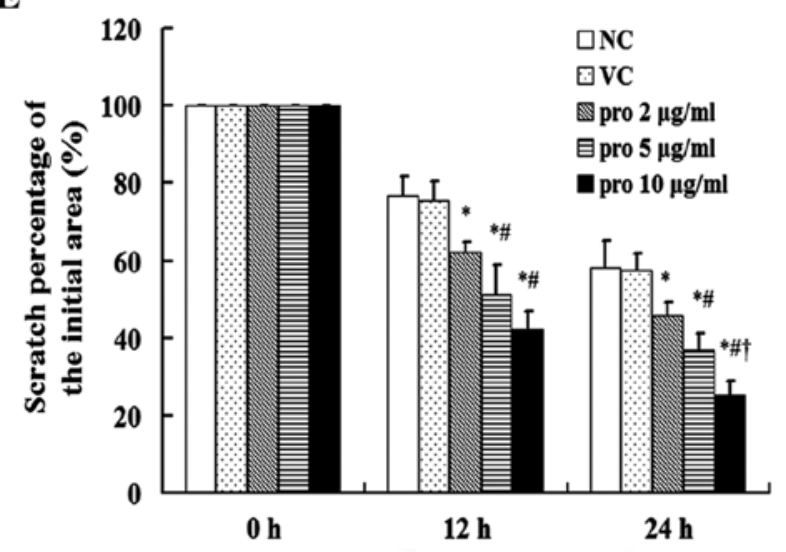

$\mathbf{F}$

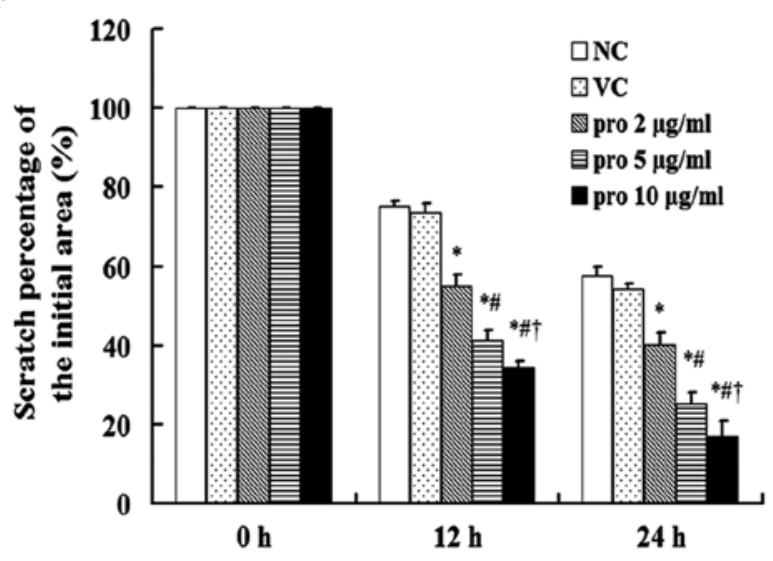

Figure 2. Effect of propofol on cell migration. After the treatment with propofol at the concentrations of 2, 5 and $10 \mu \mathrm{g} / \mathrm{ml}$ for (A) 1 , (B) 4 and (C) $12 \mathrm{~h}$, the migration of the human breast cancer cell line MDA-MB-231 was analyzed via scratch area detection at 12 and $24 \mathrm{~h}$ (magnification, x200). (D-F) The result of the wound closure assay is expressed as the percentage of the initial scratch area. Treatment with dimethyl sulfoxide (DMSO, $<0.1 \%$ ) was used as the VC group, and without propofol as the $\mathrm{NC}$ group. The migration was significantly increased after the treatment of propofol compared with the NC group, and the percentage of the initial scratch area in the propofol (pro) $10 \mu \mathrm{g} / \mathrm{ml}$ group was lower than that in the pro 2 and $5 \mu \mathrm{g} / \mathrm{ml}$ groups ( $\mathrm{P}<0.05)$. Data are shown as the mean values \pm standard deviations $(\mathrm{n}=3)$. VC, vehicle-control group; $\mathrm{NC}$, normal control group; pro, propofol. ${ }^{*} \mathrm{P}<0.05 \mathrm{vs}$. $\mathrm{NC}$ group; ${ }^{*} \mathrm{P}<0.05 \mathrm{vs}$. pro $2 \mu \mathrm{g} / \mathrm{ml}$ group; ${ }^{\top} \mathrm{P}<0.05$ vs. pro $5 \mu \mathrm{g} / \mathrm{ml}$ group.

\section{Results}

Effect of propofol on the proliferation of MDA-MB-231 cells. The cell proliferation in the VC group was not significantly different compared with that noted in the NC group. The proliferation of MDA-MB-231 cells treated with propofol was significantly increased compared with that noted in the NC group $(\mathrm{P}<0.05)$. However, cell proliferation had no significant difference after the treatment with different concentrations of propofol for $1 \mathrm{~h}$. After a 12-h treatment with propofol at the concentrations of 2,5 , and $10 \mu \mathrm{g} / \mathrm{ml}$, the proliferation was increased by $22.0 \pm 2.7,35.7 \pm 3.0$, and $51.3 \pm 4.1 \%$ compared to the $\mathrm{NC}$ group, respectively, and the proliferation following treatment with $10 \mu \mathrm{g} / \mathrm{ml}$ was higher than the proliferation following treatment with 2 and $5 \mu \mathrm{g} / \mathrm{ml}(\mathrm{P}<0.05$; Fig. 1).

Effect of propofol on the migration of MDA-MB-231 cells. The scratch area in the NC and VC groups showed similar changes 
A

B

C
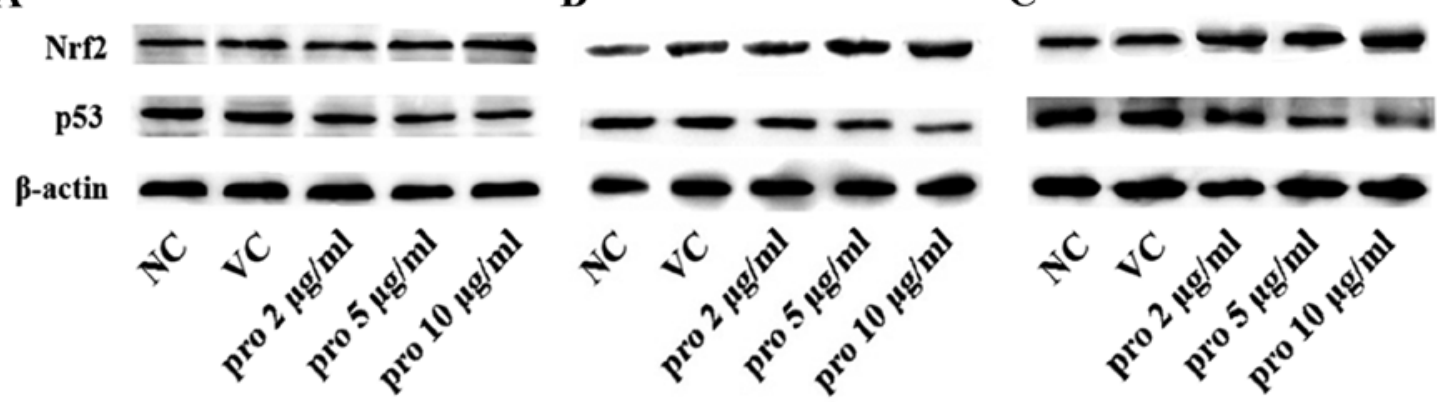

D

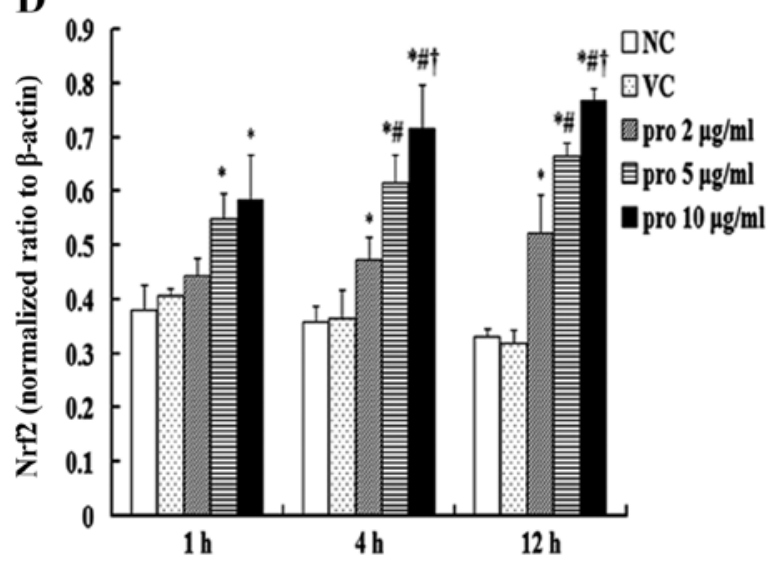

$\mathbf{E}$

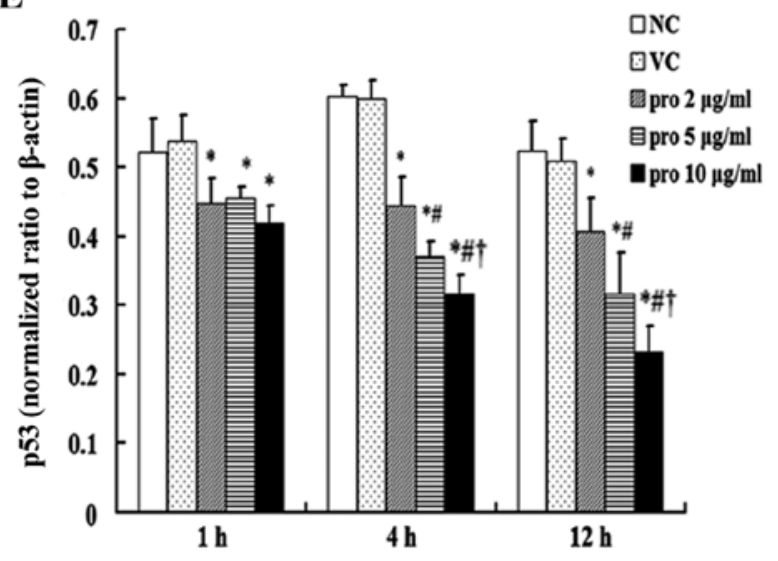

Figure 3. Effects of propofol on the expression of p53 and Nrf2 protein. The expression levels of p53 and Nrf2 protein were detected by western blot analysis after the treatment with propofol at the concentrations of 2,5 and $10 \mu \mathrm{g} / \mathrm{ml}$ for (A) 1, (B) 4 and (C) $12 \mathrm{~h}$. (D and E) Bar charts of the p53 and Nrf2 protein. The treatment with dimethyl sulfoxide (DMSO, $<0.1 \%$ ) was used as the VC group, and without propofol as the NC group. After treatment with propofol for $12 \mathrm{~h}$, the expression of 533 protein was decreased compared with the NC group, and that in the pro $10 \mu \mathrm{g} / \mathrm{ml}$ group was lower than that in the pro 2 and $5 \mu \mathrm{g} / \mathrm{ml}$ groups $(\mathrm{P}<0.05)$. On the contrary, Nrf2 was activated by propofol, and the expression in the pro $10 \mu \mathrm{g} / \mathrm{ml}$ group was higher than that in the pro 2 and $5 \mu \mathrm{g} / \mathrm{ml}$ groups $(\mathrm{P}<0.05)$. Data are shown as the mean values \pm standard deviations $(\mathrm{n}=3)$. VC, vehicle-control group; $\mathrm{NC}$, normal control group; pro, propofol. ${ }^{*} \mathrm{P}<0.05$ vs. NC group; ${ }^{*} \mathrm{P}<0.05$ vs. pro $2 \mu \mathrm{g} / \mathrm{ml}$ group; ${ }^{\dagger} \mathrm{P}<0.05$ vs. pro $5 \mu \mathrm{g} / \mathrm{ml}$ group.

with no statistical difference. After treatment with propofol for $1 \mathrm{~h}$, the scratches in the MDA-MB-231 cells treated with 5 and $10 \mu \mathrm{g} / \mathrm{ml}$ were narrower than the $\mathrm{NC}$ group and the cells treated with $2 \mu \mathrm{g} / \mathrm{ml}(\mathrm{P}<0.05)$. However, the scratch in the cells treated with 5 and $10 \mu \mathrm{g} / \mathrm{ml}$ did not differ (Fig. 2A). After treatment with propofol for $12 \mathrm{~h}$, the percentage of the initial scratch area in the cells treated with 2,5 and $10 \mu \mathrm{g} /$ $\mathrm{ml}$ propofol (40.1 $\pm 3.1,25.3 \pm 2.8$ and $17.0 \pm 3.8 \%$, respectively) were lower than the $\mathrm{NC}$ group $(57.5 \pm 2.5 \%)$ at $24 \mathrm{~h}(\mathrm{P}<0.05)$, and the percentage of the scratch area in the cells treated with $10 \mu \mathrm{g} / \mathrm{ml}$ was lower than the 2 and $5 \mu \mathrm{g} / \mathrm{ml}$ groups $(\mathrm{P}<0.05$; Fig. 2B and C).

Effects of propofol on the expression of Nrf2 and p53 protein in MDA-MB-231 cells. The expression of $\mathrm{p} 53$ and Nrf2 protein in the $\mathrm{NC}$ and $\mathrm{VC}$ groups had no significant difference. Yet, the expression of p53 protein in the 2,5 and $10 \mu \mathrm{g} / \mathrm{ml}$ propofol groups was significantly lower than that in the NC group after treatment with propofol for $1 \mathrm{~h}(\mathrm{P}<0.05)$, but no significant differences were found among the 2,5 and $10 \mu \mathrm{g} / \mathrm{ml}$ groups. After treatment with propofol for $12 \mathrm{~h}$, the expression of p53 protein in the $10 \mu \mathrm{g} / \mathrm{ml}$ group was obviously lower than that noted in the 2 and $5 \mu \mathrm{g} / \mathrm{ml}$ groups $(\mathrm{P}<0.05)$. Expression of $\mathrm{p} 53$ protein was inhibited in a dose- and time-dependent manner after treatment with propofol for 4 and $12 \mathrm{~h}$. However, the Nrf2 protein expression showed a contrary trend when compared with p53. The expression of Nrf2 protein in the $10 \mu \mathrm{g} / \mathrm{ml}$ group was significantly higher than that in the 2 and $5 \mu \mathrm{g} / \mathrm{ml}$ groups after treatment with propofol for $12 \mathrm{~h}(\mathrm{P}<0.05$; Fig. 3).

Effects of the Nrf2 inhibitor on the proliferation, migration, and p53 protein in the MDA-MB-231 cells. The proliferation of MDA-MB-231 cells in the $10 \mu \mathrm{g} / \mathrm{ml}$ group was increased significantly compared with that in the NC group. But the proliferation was decreased significantly in a dose-dependent manner after the treatment with the inhibitor of Nrf2, PIK-75 at 0.1, 0.3 and $1.0 \mu \mathrm{M}(\mathrm{P}<0.05)$. Although the proliferation was decreased after treatment with the inhibitor, it was still higher than that in the NC group $(\mathrm{P}<0.05$; Fig. 4A). After treatment with the inhibitor, the expression of Nrf2 protein was inhibited in a dose-dependent manner, while the expression of $\mathrm{p} 53$ protein was not significantly changed (Fig. 4B). Additionally, the scratch area was narrowed dramatically after exposure to propofol, which was significantly attenuated following treatment with the Nrf2 inhibitor at $1.0 \mu \mathrm{M}$ which did not differ compared with the NC group (Figs. 4C and D).

Effects of propofol and the Nrf2 inhibitor on cell apoptosis. Compared with the NC group, the caspase- 3 activity and 
A

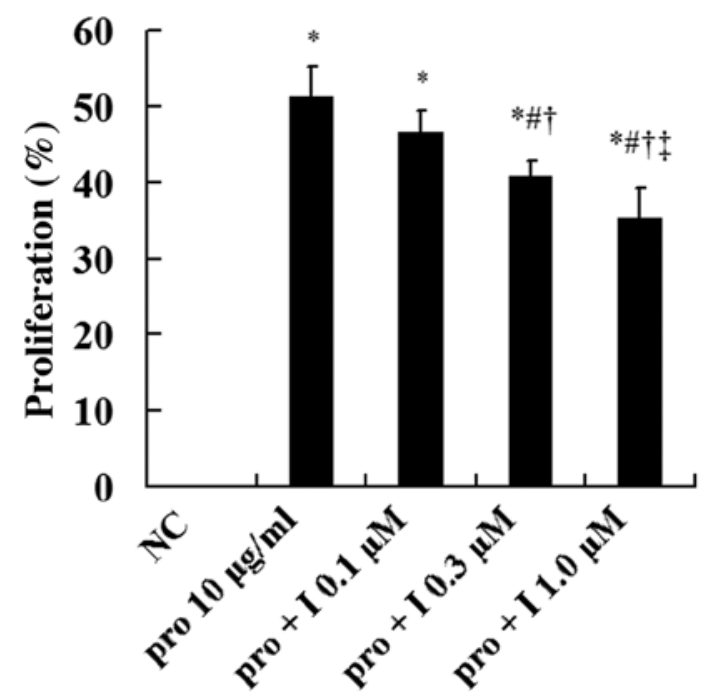

C

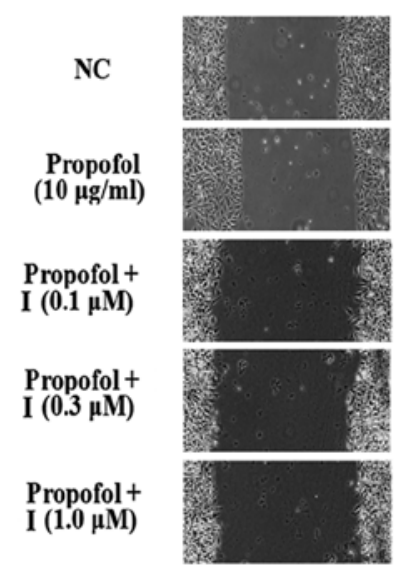

$0 \mathrm{~h}$

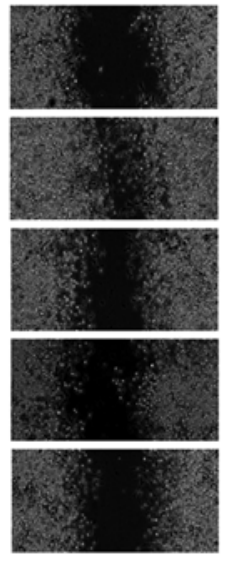

$12 \mathrm{~h}$

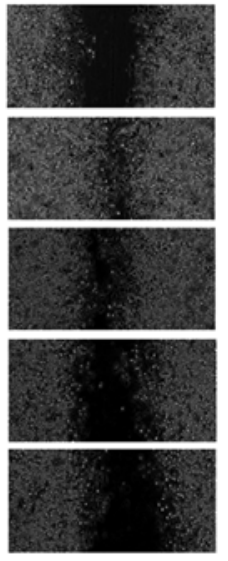

24 h
B

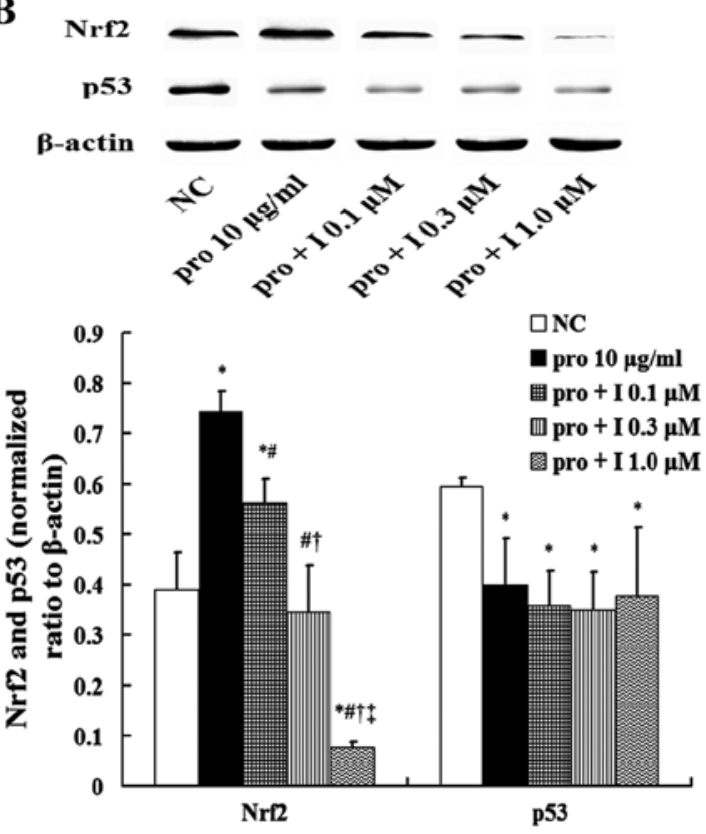

D

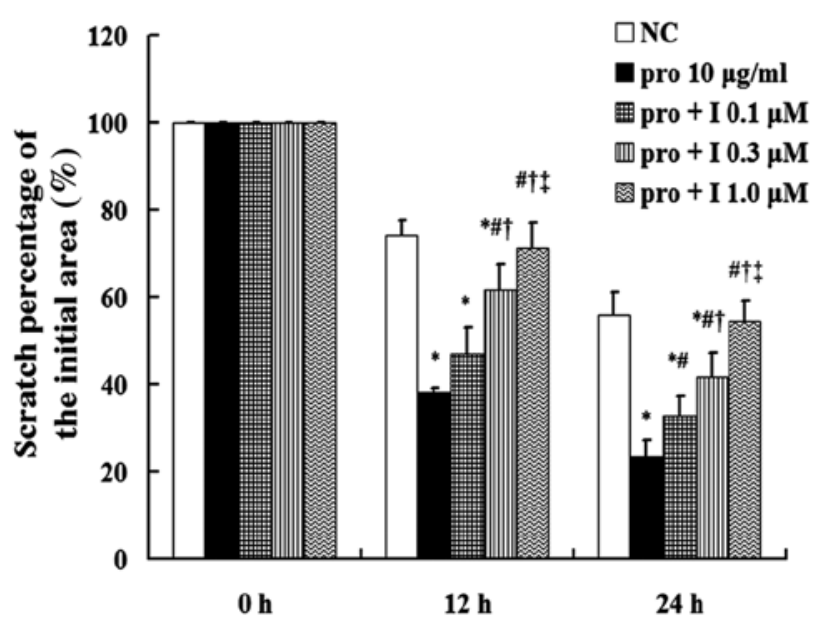

Figure 4. Effects of Nrf2 inhibitor on proliferation, migration, and p53 protein in MDA-MB-231 cells. After treatment with PIK-75, a potent Nrf2 inhibitor, at $0.1,0.3$ and $1.0 \mu \mathrm{M}$ for $4 \mathrm{~h}$, the MDA-MB-231 cells were treated with propofol at $10 \mu \mathrm{g} / \mathrm{ml}$ for $12 \mathrm{~h}$. Then, the relative indices were detected. (A) The proliferation of MDA-MB-231 cells. (B) The expression levels of p53 and Nrf2 protein, and the bar charts of the p53 and Nrf2 proteins. (C) Image of the migration assay in the MDA-MB-231 cells (magnification, x200). (D) The percentage of the initial scratch area. Compared with the NC group, the proliferation and migration in the pro $10 \mu \mathrm{g} / \mathrm{ml}$ group was increased significantly, and that in the pro $+\mathrm{I} 0.1,0.3$ and $1.0 \mu \mathrm{M}$ groups was decreased markedly compared with the pro $10 \mu \mathrm{g} / \mathrm{ml}$ group $(\mathrm{P}<0.05)$. After the treatment with propofol, the expression of $\mathrm{p} 53$ protein was decreased and the Nrf2 was increased compared with the NC group $(\mathrm{P}<0.05)$, and the expression of $\mathrm{Nrf} 2$ protein in the pro $+\mathrm{I} 1.0 \mu \mathrm{M}$ group was almost completely inhibited. However, the expression of p53 protein in the pro $10 \mu \mathrm{g} / \mathrm{ml}$ group was not different with the pro $+\mathrm{I} 0.1,0.3$ and $1.0 \mu \mathrm{M}$ groups. Data are shown as the mean values \pm standard deviations (n=3). NC, normal control group; pro, propofol; I, Nrf2 inhibitor. ${ }^{*} \mathrm{P}<0.05$ vs. $\mathrm{NC}$ group; ${ }^{\#} \mathrm{P}<0.05$ vs. pro $10 \mu \mathrm{g} / \mathrm{ml}$ group; ${ }^{\dagger} \mathrm{P}<0.05$ vs. pro $+\mathrm{I} 0.1 \mu \mathrm{M}$ group; ${ }^{\dagger} \mathrm{P}<0.05$ vs. pro $+\mathrm{I}$ $0.3 \mu \mathrm{M}$ group.

apoptosis index showed no significant difference in the VC group, which was significantly decreased after the treatment with propofol at 2,5 and $10 \mu \mathrm{g} / \mathrm{ml}$ for $12 \mathrm{~h}(\mathrm{P}<0.05)$. After the treatment with propofol at $10 \mu \mathrm{g} / \mathrm{ml}$ for $12 \mathrm{~h}$, the caspase- 3 activity and apoptosis index of the MDA-MB-231 cell were lower than these values in the 2 and $5 \mu \mathrm{g} / \mathrm{ml}$ groups $(\mathrm{P}<0.05$; Fig. 5). However, this trend was inhibited by the Nrf2 inhibitor in a dose-dependent manner. After the treatment with the inhibitor at $1.0 \mu \mathrm{M}$, the caspase-3 activity and apoptosis index were increased markedly compared with these values in the $10 \mu \mathrm{g} / \mathrm{ml}$ group $(\mathrm{P}<0.05$; Fig. 5).

\section{Discussion}

In this study, propofol induced proliferation as indicated by the MTT assay and migration as indicated by the wound healing assay in the human breast cancer cell line MDA-MB-231. Our results also showed that propofol inhibited the expression of p53, activated the Nrf2 pathway, and decreased cell apoptosis indicated by the number of TUNEL-positive cells and caspase- 3 activity. After treatment with the Nrf2 inhibitor, the TUNEL-positive cells and caspase-3 activity increased, and the migration decreased. However, the proliferation was 

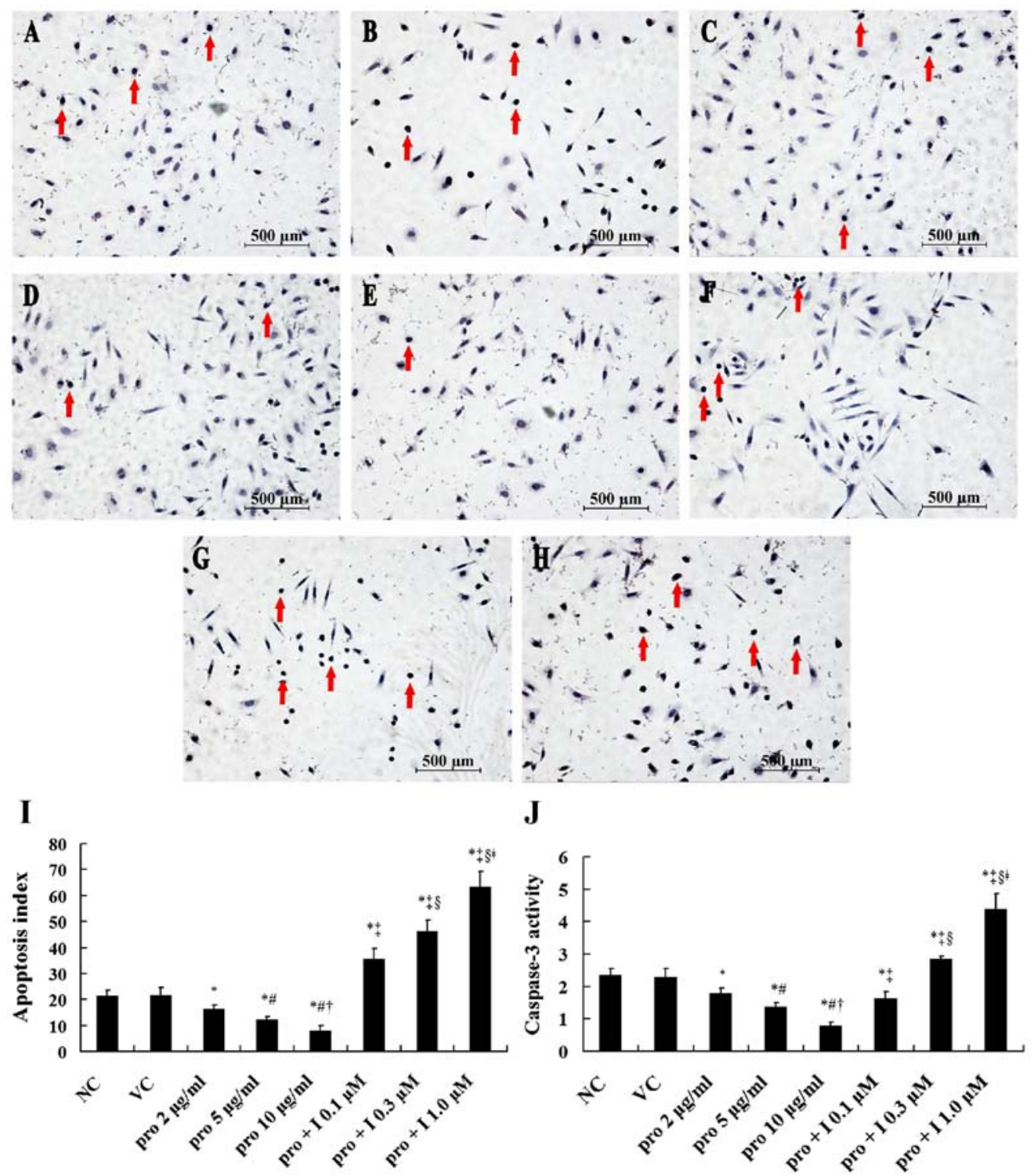

Figure 5. Cell apoptosis in the MDA-MB-231 cells after treatment with propofol and the Nrf2 inhibitor PIK-75. After treatment with propofol at concentrations of 2,5 and $10 \mu \mathrm{g} / \mathrm{ml}$ for $12 \mathrm{~h}$, the cell apoptosis was detected via terminal deoxynucleotidyl transferase dUTP nick-end labeling (TUNEL) staining and caspase-3 activity. Dimethyl sulfoxide (DMSO, $<0.1 \%$ ) and complete medium without propofol were used as the VC and NC groups. Then, following the treatment with the Nrf2 inhibitor at $0.1,0.3$ and $1.0 \mu \mathrm{M}$ for $4 \mathrm{~h}$, the MDA-MB-231 cells were treated with propofol at $10 \mu \mathrm{g} / \mathrm{ml}$ for $12 \mathrm{~h}$. The TUNEL-positive cells and caspase-3 activity were detected. Positive cells are represented by brown-yellow nuclear staining (red arrows). Figures are represented as x200 of the original magnification. Data are shown as the mean values \pm standard deviations (n=3). (A) NC group; (B) VC group; (C) pro $2 \mu \mathrm{g} / \mathrm{ml} \mathrm{group}$; (D) pro $5 \mu \mathrm{g} / \mathrm{ml}$ group; (E) pro $10 \mu \mathrm{g} / \mathrm{ml}$ group; (F) pro + I $0.1 \mu \mathrm{M}$ group; (G) pro + I $0.3 \mu \mathrm{M}$ group; (H) pro + I $1.0 \mu \mathrm{M}$ group; (I) apoptosis index; (J) caspase-3 activity. $\mathrm{VC}$, vehicle-control group; NC, normal control group; pro, propofol; I, Nrf2 inhibitor. " $\mathrm{P}<0.05$ vs. NC group; ${ }^{\circ} \mathrm{P}<0.05$ vs. pro $2 \mu \mathrm{g} / \mathrm{ml}$ group; ${ }^{~} \mathrm{P}<0.05$ vs. pro $5 \mu \mathrm{g} / \mathrm{ml}$ group; ${ }^{\dagger} \mathrm{P}<0.05$ vs. pro $10 \mu \mathrm{g} / \mathrm{ml}$ group; ${ }^{\circledR} \mathrm{P}<0.05$ vs. pro $+\mathrm{I} 0.1 \mu \mathrm{M}$ group; ${ }^{~} \mathrm{P}<0.05$ vs. pro $+\mathrm{I} 0.3 \mu \mathrm{M}$ group.

inhibited slightly and the expression of p53 protein was not affected.

p53 is recognized as a key tumor-suppressor gene and a major regulator of cell apoptosis, and p53 inhibits the proliferation of tumor cells mainly via inducing cell apoptosis (7). p53 translocates into the mitochondria and activates the mitochondrial apoptosis pathway, which is closely linked with the Bcl-2 family (7-8,13). Additionally, p53-induced cell apoptosis may be related to many other pro-apoptotic genes such as Bax, Puma, Noxa, and Bid (14). In this study, propofol inhibited the expression of p53 in MDA-MB-231 cells, and the number of apoptotic cells was decreased along with increased cell viability and proliferation. Similar results have been shown in previous studies. Antioxidants increased lung cancer cell proliferation by reducing the expression of p53 and DNA damage in mice (6). Sayin et al (15) reported that activation of p53 reduced lesional macrophage proliferation by the loss of one copy Zfp148. Zhang et al (10) found that propofol decreased the cell apoptosis and induced the proliferation of gallbladder cancer cells. Therefore, propofol induced proliferation of MDA-MB-231 cells via a decrease in the percentage of apoptotic cells, which may be through inhibition of the expression of $\mathrm{p} 53$.

$\mathrm{Nrf2}$, an important redox-sensitive transcription factor for inducing antioxidant defense system, belongs to the cap'n'collar (CNC) family of basic region-leucine zipper (bZip)-type transcription factors $(16,17)$. When Nrf2 was activated, the oxidative stress injury in cells and tissues was ameliorated, 
and the cell apoptosis was attenuated. Additionally, the Nrf2 pathway was also found to contribute to cancer initiation and progression (18). In this study, propofol activated the Nrf2 pathway in MDA-MB-231 cells, and decreased oxidative stress injury and the apoptotic index, and increased proliferation and migration. Several studies have demonstrated that propofol activates the Nrf2 pathway in gallbladder cancer cells, human alveolar epithelial cells, and lung cancer cells $(11,19,20)$. Zhang et al (21) found that Nrf2 promoted proliferation in human hepatocellular carcinoma by decreasing cell apoptosis and upregulation of the expression of anti-apoptotic protein Bcl-xL. Pan et al (22) also showed that Nrf2 is involved in the migration and invasion of human glioma cell line U251. A number of studies with similar results have been reported previously (23-26). Therefore, propofol induced the proliferation and migration of MDA-MB-231 cells, which may be related to activation of the Nrf2 pathway.

In order to confirm the possible effects of p53 and Nrf2, the Nrf2 inhibitor was used in this study. siRNA is also a potential technique for silencing a specific gene, but it may cause other genes to be overexpressed (27). Therefore, the Nrf2 PIK-75 inhibitor was used in this study. Our results showed that the Nrf2 inhibitor increased the percentage of apoptotic cells, and slightly decreased the degree of proliferation. However, the expression of p53 protein was not affected. Thus, both p53 and Nrf2 were involved in the cell apoptosis and proliferation after treatment with propofol, and propofol induced the proliferation mainly via decreased expression of p53 in the MDA-MB-231 cells. Additionally, our results also showed that the Nrf2 inhibitor completely decreased the migration induced by propofol. Therefore, Nrf2, not p53, was involved in the migration of MDA-MB-231 cells after propofol treatment.

In similar studies, Garib et al $(28,29)$ found that propofol caused cell migration via activation of the GABA-A receptor and mediating L-type calcium channels in human breast cancer cell line MDA-MB-468. In contrast to our results, Li et al (30) found that propofol inhibited the migration and invasion of human breast cancer cell line MDA-MB-231. However, in a study by Li et al, MDA-MB-231 cells were treated for $24 \mathrm{~h}$ which was longer than that used in the clinic, and whether the MDA-MB-231 cells expressed functional p53 protein was not clear. Several studies have also focused on the above issues $(31,32)$. Additionally, Deegan et al (33) revealed that proliferation of MDA-MB-231 cells treated with serum from patients who received propofol anesthesia was decreased. Because the effects of propofol were closely related to the content of extracellular albumin (34), the composition of serum from patients was too complex to assess the role of propofol itself. In this study, clinically relevant doses of propofol were selected and administered for appropriate times as in surgery $(30-31,35)$. Therefore, our study clearly showed the effects of propofol itself on the MDA-MB-231 cells.

In conclusion, propofol increased the cell proliferation at least partially via the inhibition of p53, and induced the migration via the activation of $\mathrm{Nrf} 2$ in the human breast cancer cell line MDA-MB-231. However, whether these effects can be applied to other cancer cells or normal tissue cells, and different cancer cell types will be investigated in future research. Additionally, further in vivo studies, including animal trials and prospective clinical studies, are warranted.

\section{References}

1. Choi YK, Por ED, Kwon YG and Kim YM: Regulation of ROS production and vascular function by carbon monoxide. Oxid Med Cell Longev 2012: 794237, 2012.

2. Clarke MW, Burnett JR and Croft KD: Vitamin E in human health and disease. Crit Rev Clin Lab Sci 45: 417-450, 2008.

3. Rayman MP: Selenium and human health. Lancet 379: 1256-1268, 2012.

4. Serafini M, Bellocco R, Wolk A and Ekström AM: Total antioxidant potential of fruit and vegetables and risk of gastric cancer. Gastroenterology 123: 985-991, 2002.

5. Kong Q and Lillehei KO: Antioxidant inhibitors for cancer therapy. Med Hypotheses 51: 405-409, 1998.

6. Sayin VI, Ibrahim MX, Larsson E, Nilsson JA, Lindahl P and Bergo MO: Antioxidants accelerate lung cancer progression in mice. Sci Transl Med 6: 221ra15, 2014.

7. Wolff S, Erster S, Palacios G and Moll UM: p53's mitochondrial translocation and MOMP action is independent of Puma and Bax and severely disrupts mitochondrial membrane integrity. Cell Res 18: 733-744, 2008

8. Leu JI, Dumont P, Hafey M, Murphy ME and George DL: Mitochondrial p53 activates Bak and causes disruption of a Bak-Mcl1 complex. Nat Cell Biol 6: 443-450, 2004.

9. Marik PE: Propofol: Therapeutic indications and side-effects. Curr Pharm Des 10: 3639-3649, 2004.

10. Zhang L, Wang N, Zhou S, Ye W, Jing G and Zhang M: Propofol induces proliferation and invasion of gallbladder cancer cells through activation of Nrf2. J Exp Clin Cancer Res 31: 66, 2012.

11. Xu YB, Du QH,Zhang MY, Yun P and He CY: Propofol suppresses proliferation, invasion and angiogenesis by down-regulating ERK-VEGF/MMP-9 signaling in Eca-109 esophageal squamous cell carcinoma cells. Eur Rev Med Pharmacol Sci 17: 2486-2494, 2013.

12. Duong HQ, Yi YW, Kang HJ, Hong YB, Tang W, Wang A, Seong YS and Bae I: Inhibition of NRF2 by PIK-75 augments sensitivity of pancreatic cancer cells to gemcitabine. Int $J$ Oncol 44: 959-969, 2014.

13. Chakraborty S, Mazumdar M, Mukherjee S, Bhattacharjee P, Adhikary A, Manna A, Chakraborty S, Khan P, Sen A and Das T: Restoration of $\mathrm{p} 53 / \mathrm{miR}-34 \mathrm{a}$ regulatory axis decreases survival advantage and ensures Bax-dependent apoptosis of non-small cell lung carcinoma cells. FEBS Lett 588: 549-559, 2014.

14. Moll UM, Marchenko N and Zhang XK: p53 and Nur77/ TR3-transcription factors that directly target mitochondria for cell death induction. Oncogene 25: 4725-4743, 2006.

15. Sayin VI, Khan OM, Pehlivanoglu LE, Staffas A, Ibrahim MX, Asplund A, Agren P, Nilton A, Bergström G, Bergo MO, et al: Loss of one copy of $\mathrm{Zfp} 148$ reduces lesional macrophage proliferation and atherosclerosis in mice by activating p53. Circ Res 115: 781-789, 2014.

16. Moi P, Chan K, Asunis I, Cao A and Kan YW: Isolation of NF-E2-related factor 2 (Nrf2), a NF-E2-like basic leucine zipper transcriptional activator that binds to the tandem NF-E2/AP1 repeat of the beta-globin locus control region. Proc Natl Acad Sci USA 91: 9926-9930, 1994.

17. Maher J and Yamamoto M: The rise of antioxidant signaling - the evolution and hormetic actions of Nrf2. Toxicol Appl Pharmacol 244: 4-15, 2010.

18. Jaramillo MC and Zhang DD: The emerging role of the Nrf2-Keap1 signaling pathway in cancer. Genes Dev 27: 2179-2191, 2013.

19. Hsu HT, Tseng YT, Hsu YY, Cheng KI, Chou SH and Lo YC: Propofol attenuates lipopolysaccharide-induced reactive oxygen species production through activation of Nrf2/GSH and suppression of NADPH oxidase in human alveolar epithelial cells. Inflammation 38: 415-423, 2015.

20. Chen J, Zhao WH, Song ZJ, Chen HG, Xie KL, Zhao XX and Lei GY: Effects of propofol on proliferation and apoptosis of HCC827 cells. Journal of Xi'an Jiaotong University (Medical Sciences) 3: 361-363, 384, 2014 (In Chinese).

21. Zhang M, Zhang C, Zhang L, Yang Q, Zhou S, Wen Q and Wang J: Nrf2 is a potential prognostic marker and promotes proliferation and invasion in human hepatocellular carcinoma. BMC Cancer 15: 531, 2015.

22. Pan H, Wang H, Zhu L, Mao L, Qiao L and Su X: The role of Nrf2 in migration and invasion of human glioma cell U251. World Neurosurg 80: 363-370, 2013 
23. Wang J, Zhang M, Zhang L, Cai H, Zhou S, Zhang J and Wang Y: Correlation of Nrf2, HO-1, and MRP3 in gallbladder cancer and their relationships to clinicopathologic features and survival. J Surg Res 164: e99-e105, 2010.

24. Ma RQ, Zhang MX, Wang JS, Cai H, Yeer MK and Duan XY: Expression and distribution of Nrf2 in several hepatocellular carcinoma cell lines. Xi Bao Yu Fen Zi Mian Yi Xue Za Zhi 27 608-610, 2011 (In Chinese).

25. Mao JT, Tangsakar E, Shen H, Wang ZQ, Zhang MX, Chen JX Zhang $G$ and Wang JS: Expression and clinical significance of $\mathrm{Nrf} 2$ in esophageal squamous cell carcinoma. Xi Bao Yu Fen Zi Mian Yi Xue Za Zhi 27: 1231-1233, 2011 (In Chinese).

26. Zhou S, Ye W, Shao Q, Zhang M and Liang J: Nrf2 is a potential therapeutic target in radioresistance in human cancer. Crit Rev Oncol Hematol 88: 706-715, 2013.

27. Kesharwani P, Gajbhiye V and Jain NK: A review of nanocarriers for the delivery of small interfering RNA. Biomaterials 33 : 7138-7150, 2012

28. Garib V, Niggemann B, Zänker KS, Brandt L and Kubens BS Influence of non-volatile anesthetics on the migration behavior of the human breast cancer cell line MDA-MB-468. Acta Anaesthesiol Scand 46: 836-844, 2002.

29. Garib V, Lang K, Niggemann B, Zänker KS, Brandt L and Dittmar T: Propofol-induced calcium signalling and actin reorganization within breast carcinoma cells. Eur J Anaesthesiol 22: 609-615, 2005
30. Li Q, Zhang L, Han Y, Jiang Z and Wang Q: Propofol reduces MMPs expression by inhibiting NF- $\kappa \mathrm{B}$ activity in human MDA-MB-231 cells. Biomed Pharmacother 66: 52-56, 2012.

31. Ecimovic P, Murray D, Doran P and Buggy DJ: Propofol and bupivacaine in breast cancer cell function in vitro - role of the NET1 gene. Anticancer Res 34: 1321-1331, 2014.

32. Siddiqui RA, Zerouga M, Wu M, Castillo A, Harvey K, Zaloga GP and Stillwell W: Anticancer properties of propofol-docosahexaenoate and propofol-eicosapentaenoate on breast cancer cells. Breast Cancer Res 7: R645-R654, 2005.

33. Deegan CA, Murray D, Doran P, Ecimovic P, Moriarty DC and Buggy DJ: Effect of anaesthetic technique on oestrogen receptor-negative breast cancer cell function in vitro. Br J Anaesth 103: 685-690, 2009.

34. Belouchi NE, Roux E, Savineau JP and Marthan R: Interaction of extracellular albumin and intravenous anaesthetics, etomidate and propofol, on calcium signalling in rat airway smooth muscle cells. Fundam Clin Pharmacol 14: 395-400, 2000.

35. Cui WY, Liu Y, Zhu YQ, Song T and Wang QS: Propofol induces endoplasmic reticulum (ER) stress and apoptosis in lung cancer cell H460. Tumour Biol 35: 5213-5217, 2014. 